\title{
An Analysis of Innovative and Entrepreneurial Education in Higher Vocational Colleges from Ideological and Political Education
}

\section{Lincheng Huang}

\author{
Guangdong Polytechnic of Water Resources and Electric Engineering
}

Keywords: ideological and political education; higher vocational college; innovation education

\begin{abstract}
With the vigorous development of education in our country, the national higher vocational colleges focus on cultivating high-quality talents, and integrate innovative and entrepreneurial education methods into the daily education, which become the necessary conditions for higher vocational colleges' reform and innovation and an inevitable trend of the development of ideological and political education. The combination of ideological and political education with innovative and entrepreneurial education in higher vocational colleges to create a good teaching atmosphere are three education goals of ideological and political education in the new era. This paper mainly introduces that in the process of ideological and political education in higher vocational colleges, it is essential to guide students to think correctly, cultivate high-quality talents, vigorously promote students' entrepreneurial activities on campus, strengthen students' innovative practice and effectively strengthen their innovative and entrepreneurial abilities. It is also proposed to improve students' practical ability, carry out ideological and political education at the same time and strengthen their employment competitiveness, laying a good foundation for the future step into the society.
\end{abstract}

\section{Introduction}

With the increasing employment competition for in our country, colleges and universities throughout the country advocate the students to carry out innovative practices, make full use of the professional skills they have learned, constantly practice and innovate, and effectively improve themselves in all aspects. In the traditional teaching of colleges and universities, it emphasizes the specialized knowledge teaching, but seriously neglects to train student's innovation practice spirit and entrepreneurial spirits and affects their employment competition ability, therefore, graduates tend to be confused by the phenomenon when they enter the society. This article mainly carries on the discussion according to the above questions. At present, higher vocational colleges in our country must strengthen the cultivation of students' innovative consciousness, make clear stipulates, strengthen students' innovative abilities, further enhance Ideological and Political Education in higher vocational colleges, integrate innovative consciousness into the teaching of political education, and strengthen students' professional ability and innovative ability.

\section{Advantages of Innovative and Entrepreneurial Education}

Most higher vocational colleges in our country carry out Ideological and Political Education in a traditional way and there are no practical contents inside and outside the school with a mechanical and single traditional teaching method. With the implementation of Innovative and Entrepreneurial Education activities, a diversified practical environment has been formed, for example, the traditional teaching methods are scientifically and reasonably innovated, the practice bases are rationally utilized, and the practical cooperation with social enterprises is vigorously carried out. All of these are capable of expanding the scope of Ideological and Political Education in colleges and universities, make it more closer to the real life and the actual working environment, and integrate theoretical education and practical education effectively, all of which accord with the teaching goals of Ideological and Political Education in higher vocational colleges.

According to the analysis of present situation, there are many problems existing in the traditional 
teaching methods of higher vocational colleges in our country: Firstly, it is common to regard the Ideological and Political Education as a very idealized teaching and aims to shape a completely idealized college student, which is completely not in line with reality. Secondly, in the traditional process of Ideological and Political Education in colleges and universities, the subjective teaching problem of teachers is too serious. Among students, teachers have considerable authority and are regulated to obey the conformity principles. There is no peaceful and democratic exchange as well as condition for peaceful coexistence between teachers and students at all. Thirdly, the traditional Ideological and Political Education in higher vocational colleges is too single to effectively utilize students' differences in teaching. We always only focus on teaching professional skills, but neglect students' feelings, their ability to innovate independently and so on. All of these existing problems lead to the fact that Ideological and Political Education in higher vocational colleges cannot realize the diversified development and individualized innovation of students, failing to use professional skills flexibly and lacking practical ability of professional skills. Innovative and Entrepreneurial Education pays more attention to the individuation and difference of students, create a teaching environment that can be freely used for college students, focus on developing their personal and potential abilities, develop their autonomy and creativity, and develop their personal abilities, such as creative ability, practical ability, professional skills, application ability, etc. Therefore, according to the development trend of students, Innovative and Entrepreneurial Education can greatly improve the teaching effect of Ideological and Political Education in higher vocational colleges.

\section{Advantages of Ideological and Political Education}

Entrepreneurial thinking is an important content of innovation and entrepreneurship. In the process of Ideological and Political Education, students' consciousness of innovation and entrepreneurship is effectively developed, playing an important role. During the process, we impart the concept of innovation, innovate the knowledge of entrepreneurship, train high quality talents conforming to the teaching standards of higher vocational colleges in our country, improve the competitiveness of students' employment entrepreneurship, consciously carry out innovation, and make students have a good sense of innovative and entrepreneurial awareness and practical ability. With the method of guidance, higher vocational colleges fully understand the relationship between innovation and entrepreneurship with social employment. Colleges cultivate students' professional skills and professional qualities according to the needs of social enterprises, transform passive employment into active employment, and strive for greater employment opportunities. It is beneficial to the balanced development of Chinese enterprises and to the cultivation of high-quality talents.

Ideological and Political Education effectively cultivates students' innovative and entrepreneurial spirits as well as social practical ability. The combination of Ideological and Political Education and social needs in higher vocational colleges can set up good ideas for students, inculcate the communist thoughts and the common ideal of our country, effectively improve the ideological and moral quality as well as innovation ideas of college students in our country, cultivate their innovative and entrepreneurial confidence, arouse their interests and confidence in starting a business independently, cultivate their strong convictions, and ability to live independently and a high level of entrepreneurial awareness, etc, all of which can make students able to calmly face all kinds of difficulties in entrepreneurship with favorable entrepreneurial environment and innovative consciousness.

The course of Ideological and Political Education in colleges and universities has a positive effect on entrepreneurial activities, which is conducive to the cultivation of high-quality talents with innovative and entrepreneurial spirits. It is also the ultimate aim to integrate Ideological and Political Education into innovative entrepreneurial awareness in higher vocational colleges. It has a great effect on students when they step into the society and provides favorable conditions for students' social entrepreneurship.

Firstly, in the theoretical teaching, Ideological and Political Education in colleges and universities has an important significance so that students have a good social communication ability 
and excellent entrepreneurial practical ability in social practice and entrepreneurship. Secondly, Ideological and Political Education in higher vocational colleges are able to strengthen the practical activities, strengthen students' innovative and practical ability, enhance their strong consciousness, improve their comprehensive ability, and achieve the goal of cultivating enterprising talents in colleges and universities.

\section{Innovative and Entrepreneurial Education based on Ideological and Political Education in Higher Vocational Education}

At present, the education of higher vocational colleges in our country is mainly a people-oriented education system, which effectively avoids the machinery of traditional teaching, pays attention to students' Ideological and Political Education, encourages students to carry out practical innovation, and trains their patriotic feelings, which are able to make students devote themselves to the creative and entrepreneurial activities. Therefore, Ideological and Political Education should be added to the teaching of innovative and entrepreneurial teaching, so as to effectively train students' entrepreneurial ability.

With the rapid development of social economy, the society is more and more eager for high-quality talents, and the country attaches more and more importance to entrepreneurship and innovation. Therefore, higher vocational colleges need to impart various forms of innovative and entrepreneurial models according to students' actual conditions. It is advantageous for students to start their own business in the field they are good at. The ideological and political teaching in higher vocational colleges analyze the new situation of entrepreneurship in our country more comprehensively for students and help them to choose a form of entrepreneurship that adapts to current policies according to the direction of national policy.

In the traditional ideological and political teaching in colleges and universities, we just taught ideology and politics, but the current environment of social entrepreneurship requires schools to make certain adjustments to change the teaching concepts and to establish a perfect teaching system. Higher vocational colleges should make full use of the advantages of Ideological and Political Education courses, incorporate innovative and entrepreneurial sense into daily teaching, according to the actual situation of students and the surrounding social environment, and effectively combine entrepreneurship with ideological and political teaching based on the actual situations of students and the surrounding social environment.

According to the present stage of national development, higher vocational colleges can adapt to the modern social environment and cultivate high-quality talents to adapt to the modern social environment, only by strictly following the direction of national policies. We are suggested to incorporate Innovative and Entrepreneurial Education into the ideological and political teaching in colleges and universities, follow the socialist road with Chinese characteristics, hold various practical entrepreneurial activities in teaching and effectively arouse students' passion and enthusiasm for entrepreneurship. It is also proposed to train students' comprehensive ability in daily activities, make students choose independently their own entrepreneurial goals, improve their professional skills and innovative practical ability, improve their social employment competitiveness, and help students to step into the society more quickly and determine their position under the social background. To infiltrate Ideological and Political Education into Innovative and Entrepreneurial Education, the main contents are as follows: First, in compulsory courses, we need to add the course of Ideological and Political Education as the main teaching contents, attract students to attach importance to Ideological and Political Education and the necessity of learning. Second, in daily teaching, we should add Innovative and Entrepreneurial Education to students' consciousness, which is beneficial to the development of entrepreneurial practice. Third, we should carry out various forms of elective courses in higher vocational colleges that will make students choose entrepreneurial courses according to their interests and hobbies.

Higher vocational colleges need to train students in a unified way, create a favorable environment for entrepreneurship, and make great efforts to cultivate students' ability to set up their own businesses. At present, most colleges and universities in our country are still carrying out the 
traditional teaching, which make students fail to combine effectively theories with practice when they enter the society and can not effectively help them in social employment. In order to strengthen their graduation employment rate, some colleges and universities even do not carry out Innovative and Entrepreneurial Education. Therefore, we must carry out Ideological and Political Education in higher vocational colleges and keep pace with the times, set up correct values of life and world outlook for students, effectively innovate traditional teaching methods, encourage college students to start their own businesses, create a good environment for them and effectively cultivate their' ability of independent entrepreneurial and social practice, so that student will be able to adapt to the development of modern society and enable them to contribute to the economic development of our country when they step into the society.

\section{Conclusion}

According to the above contents, Ideological and Political Education carried out in higher vocational colleges can set up a correct outlook on life for students, improve students' ideological and moral character, integrate Innovative and Entrepreneurial Education into Ideological and Political Education, cultivate their entrepreneurial ability and social practice ability effectively and create a good entrepreneurial conditions, so that students will be capable of adapting to the development of society and enhance students' competitiveness in employment. Besides, it is also beneficial for students to apply their professional skills to practical work and integrate themselves into social work more quickly. At the present stage, higher vocational colleges need to reform the traditional teaching, infiltrate Ideological and Political Education into students' education of innovative and entrepreneurial, organize a variety of entrepreneurial activities to cultivate students' entrepreneurial ability, train more high-quality talents for our country, and promote the healthy development of our economy.

\section{References}

[1] Li Lin. An Analysis of Innovative and Entrepreneurial Education in Higher Vocational Colleges from the Perspective of Ideological and Political Education [J]. Journal of Jiamusi Vocational Institute, 2016,08:136-137.

[2] Fang Weizhong, Wang Meijuan. Exploration and Practice of Higher Vocational Employment Education System and Psychological Quality Training based on Innovative and Entrepreneurial Education [J]. Knowledge Based Economy, 2016,22:176-177.

[3] Zhang Weihua, Sun Wenjuan. An Analysis of Innovative and Entrepreneurial Education in Higher Vocational Colleges from the Perspective of Ideological and Political Education [J]. Journal of Higher Education, 2017,09:174-175.

[4] Huang Jing. The Application of Entrepreneurship Education to Ideological and Political Education of Higher Vocational Colleges [J]. Communication of Vocational Education, 2014,35:58-60.

[5] Zhan Zhonggen, Xu Yaping. Research on Ideological and Political Education of Poor Students in Higher Vocational Colleges from the Perspective of Employment Guidance [J]. Career Horizon, 2015,1109:82-85.

[6] Zhang Jian. An Analysis of the Effectiveness of Ideological and Political Education in Higher Vocational Colleges - Research and Practice based on the Theory of Social Entrepreneurship Education [J]. Contemporary Vocational Education, 2014,01:85-88. 